\title{
SETENTA, DE HENRIQUE SCHNEIDER: TORTURA, TRAUMA E TRANSFORMAÇÕES NO TEXTO FICCIONAL
}

HENRIQUE SCHNEIDER'S NOVEL SETENTA: TORTURE, TRAUMA AND TRANSFORMATION IN THE FICTIONAL TEXT

Jeferson de Moraes Jacques*

RESUMO: A história brasileira é permeada pela violência desde seu início. A segunda década do século XXI, no Brasil, carrega como marca a presença de políticos e formadores de opinião com discursos que frequentemente referenciam e até fazem homenagens ao período da ditadura militar e a alguns de seus representantes. Isso divide a população: alguns são favoráveis, outros, notavelmente a classe artística, são contra, o que motivou produções artísticas diversas sobre este período. O romance Setenta, de Henrique Schneider, cujo texto original foi vencedor do Prêmio Paraná de Literatura em 2017, apre to Raul que, em meio à efervescê pela Copa de 1970, é um dedicado bancário, retrato fiel do cidadão brasileiro indiferente à política, o que lhe trará uma terríve experiência traumática que se distancia, mas está presente e de xa marcas até mesmo na forma dos escritos literários que falam sobre este período.

PALAVRAS-CHAVE: Setenta. Henrique Schneider. Ditadura. Tortura. Tortura. jeferson.montag@gmail.com

Mestrando em Teoria Literária na Pontifícia Universidade Católica do Rio Grande do Sul (Porto Alegre - RS)

ABSTRACT: Brazilian history is permeated by violence since its beginning. The second decade of the 21st century in Brazil has as its mark the presence of politicians and opinion makers with speeches that often refer to and honor the period of the military dictatorship and some of its representatives. This divides the population: some are favorable, others, notably the artistic class, are against, and this has motivated a number of artistic productions about this period. Henrique Schneider's novel Setenta, whose original text won the 2017 Paraná Literature Prize, features protagonist Raul, who, amid the effervescence of patriotism whe 1970 World Cup, is a dedicated banker, a faith ful poted by the 1970 World Cup, is a dedicated bank, a faithful portrait of the Brazilan cilizen indifferent to politics. He faces a terrible and traumatic experience that goes away, but is presen and leaves marks even in the form of literary writings that refer to this period.

KEYWORDS: Setenta. Henrique Schneider. Dictatorship. Torture. 


\section{INTRODUÇÃO}

O Brasil, desde a chegada dos colonizadores portugueses à América, passa por atos de violência de diversas formas. Em seu início, houve a imposição da soberania portuguesa contra os índios ao suprimir sua cultura Posteriormente, houve o tráfico de pessoas trazidas como escravas de países africanos, e as consequências desse período se fazem ainda visíveis na forma de violência social e associação da população negra à criminalidade, à servidão e à inferioridade. No século XX, o país passou por regimes totalitários, como o Estado Novo de Getúlio Vargas, que durou de 1937 até 1945. Com o golpe, em 1964, iniciou-se a ditadura militar, que teve seu final apenas em 1985 com a redemocratização. Uma característica marcante desse período foi a violação dos direitos humanos e perseguições aos opositores, ou a quem os militares julgassem como tal. Com o fim do regime, tais momentos traumáticos não parecem ter terminado de forma conciliadora, pois ainda há uma forte presença deles no cotidia no brasileiro, dada a dificuldade que a política brasileira tem em manter e aprimorar sua democracia. De tempos em tempos, há uma tentativa de voltar ao passado.
Temos uma história republicana com heranças sólidas da exploração colonial e do império escravista. Nunca, a rigor, tivemos uma democracia em seu sentido mais rigoroso. [...] Somos um país em que o autoritarismo é fortemente constitutivo das bases da formação social. Naturaliza mos por essa razão tudo o que deveria nos deixar perplexos - violência excessiva por parte do Estado, enorme desigualdade social, ausência de prerrogativas éticas nas condições de convivência social, permanente estado de expectativa incerta quanto ao futuro, ausência de condições de escolarização compatíveis com as necessidades sociais e com as exigências para a formação de consciência crítica coletiva. Naturalizamos, muitas vezes sem perceber com clareza, várias formas, algumas a menas e outras trágicas, de barbárie. (GINZBURG, 2001, 121)

A segunda década do século XXI, no Brasil, traz uma presença notável de políticos e formadores de opinião com discursos que frequentemente referenciam e até fazem homenagens à ditadura militar e a alguns de seus representantes, de modo a negar ou minimizar os momentos mais cruéis desse período, como os exílios e as torturas.

Em 2016, instabilidades econômicas, fortes manifestações e uma manobra da oposição motivaram o impeachment da então presidente da república Dilma Rousseff. Durante a votação feita pelos deputados, o atual 
2. Disponível em < https://www1.
folha.uol.com.br/mundo/2019/0 olsonaro-ataca-pai-de-bachelet-quefoi-torturado-e-morto-pela-ditadurapinochet.shtml? loggedpaywall\#_ = $>$ Publicado em 4 set. 2019. Acesso: 22 out. 2019 presidente da república, à época deputado federal, fez referência ao golpe de 1964 e dedicou seu voto ${ }^{1}$ ao Corone Carlos Alberto Brilhante Ustra, ex-chefe do DOI-Codi (Destacamento de Operações de Informação - Centro de Operações de Defesa Interna), órgão de inteligência e repressão do governo brasileiro, que, subordinado ao exército, atuou durante o período da ditadura militar. O já falecido coronel foi o primeiro militar reconhecido pela Justiça como torturador, tendo sido condenado em 2012 Já em 2019, devido a um comentário de Michelle Bachelet, alta comissária da ONU para direitos humanos e ex-presidente do Chile, de que o Brasil sofre uma "redução do espaço democrático", o já presidente atacou o pai da comissária, Alberto Bachelet, general de brigada da Força Aérea chilena que foi preso, torturado e morto por ter feito oposição ao golpe militar de Pinochet em 1973². Declarações como as do presidente, desde antes de sua eleição, além de postagens e falas de outras a utoridades políticas alinhadas a ele, ecoam nas redes sociais e reverberam o pensamento de muitos de seus eleitores, majoritariamente conservadores e simpatizantes do período militar brasileiro. Tais posiciona mentos, já existentes de modo velado, passaram a se fazer presentes de modo direto, minimizando, assim o caráter assumida mente antidemocrático do regime militar, que perseguia, torturava e matava opositores.
Porém, simulta neamente há uma reação contrária por parte da população e da classe artística, manifestada por atos e manifestações ${ }^{3}$ em diversas localidades do país, e a produção de diversas peças cujo universo ficcional se encontra nesse período, como o romance Setenta, do escritor gaúcho Henrique Schneider. O texto original do livro foi vencedor do Prêmio Paraná de Literatura em 2017. Curiosamente, Setenta foi publicado no mesmo período em que o AI-5 (Ato Institucional número 5) havia completado cinco décadas de sua publicação. O AI-5 foi o quinto de dezessete atos institucionais que, além de permitir ao presidente que fechasse o congresso, demitisse servidores públicos e cassasse mandatos, lhe daria permissão para intervir em estados e municípios. Com essa medida, os militares ${ }^{4}$ também ganharam autonomia para prender e intimidar cidadãos de forma arbitrá ria e violenta, além de exercer um controle rigoroso nas produções culturais, submetidas à censura, o que repercutiu no meio jornalístico e artístico, resultando em perseguições e exílios. Henrique Schneider aponta, por meio de Raul, personagem principal de seu romance, um típico cidadão brasileiro que, avesso à política, sofre as consequências disso enquanto vive no Brasil em 1970, época de grande euforia devido à Copa do Mundo e o AI5 em andamento.
1. Disponível em https://revistaforum . com.br/noticias/bolsonaro-dedicavoliting

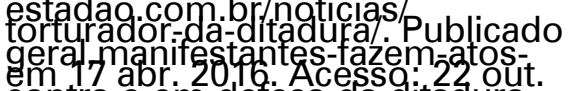
289iga-e-en-desa-da-ditadurarmilitar-pelo-brasil,70002774764 Acesso: 21 out. 2019
4. Disponível em< http://www. planalto.gov.br/ccivil_03/AIT/ait-05-
68.htm > Acesso: em 22 out. 2019. 
A complexidade da experiência de Raul, difícil de ser recriada pela ficção, tal como qualquer acontecimento traumático em um país, afeta não apenas a linguagem e o modo de pensar, mas também acarreta mudanças intencionais ou não - na forma do próprio texto que a representa.

\section{1 "EU SOU SÓ UM BANCÁRIO"}

O personagem Raul, protagonista de Setenta, é um rapaz de 25 anos, dedicado bancário que morava com os pais, tinha uma namorada (que o deixara misteriosamente), alternava seu trabalho com algumas atividades de lazer, como cinema, e era completa mente indiferente à política, não a via como algo com que realmente devesse se interessar.

Até uns dias atrás, Raul nem sabia que existiam razões para alguém querer derrubar o governo. Tudo ia bem no país, bem como diziam na tevê, o rádio, os jornais. Vidinha regrada, e o que fosse além era assunto que não importava, que não lhe dizia respeito. Estes loucos dos qua is às vezes ouvia falar, aqueles que assaltava m bancos e sequestravam gente, eram, para Raul, apenas isso mesmo: loucos. Ou criminosos. (SCHNEIDER, 2019, p. 148)
Certo dia, saiu para ir ao cinema e tomar uma cerveja, vestindo uma camisa vermelha. Foi quando passou correndo por ele outro homem, com camisa semelhante: tratava-se de um opositor do governo, que fazia parte de um grupo que tentara sequestrar o cônsul norte-a merica no Curtis Carly Cutter. Devido à semelhança da camisa, a polícia equivocadamente prendeu Raul.

Tudo foi tão rápido quanto incompreensível. Raul recém havia dobrado a esquina e andava por uma ruela próxima à Andradas, indo para o cinema, quando o rapaz miúdo e de camisa vermelha passou por ele numa corrida desesperada [...]. Rau nem tivera tempo de compreender o que podia significar aquela corrida, quando o Corcel dobrou a esquina da ruazinha cantando pneus, canto de ameaça. O automóvel freou logo ao lado de Raul, que estacara o passo sem saber o que estava acontecendo, e dele descera $m$ dois homens, armados de gritos e pistolas [...]. Um dos homens pegou Raul pelo pescoço e deu-lhe um safanão, outro o empurrou sem cuidado para dentro do carro, ambos despreocupados do barulho que faziam, da atenção que poderiam estar chamando. [...]

- Mas o que é isso? O que é isso? [...]

- Cala a boca, filho da puta, e entra no carro. [...] (SCHNEIDER, 2019 , p. $19-20)$ 
A maior parte da narrativa é centrada no período em que Raul esteva preso, e possui descrições detalhadas dos momentos de interrogatório e diversas torturas físicas e psicológicas pelas quais o personagem passou.

- Não sei de nada.

- Sabe, sim. [...] - Fez um novo sinal aos homens, apenas um aceno com o queixo, e eles começaram a desenrolar os fios do aparato elétrico. [...] Fixaram as pontas dos fios na orelha esquerda e no mamilo direito do prisioneiro, enqua nto comentavam entre si que o conjunto havia ficado bonito. Verificaram se os fios estavam bem firmes e então o aluno mais aplicado começou a rodar a manivela. Rodou-a sem pressa, percebendo que o corpo do prisioneiro tremia em partes, como que se dando conta aos poucos do que lhe acontecia, o silêncio se transformando em lamentos que mais adiante se transformavam em gemidos que logo se transformavam em gritos que se transformavam em uivos tristes e cada vez mais inúteis. (SCHNEIDER, 2019, p. 120)

A maior carga de tensão na narrativa está localizada no capítulo 15, quando Raul, recém-solto, finalmente consegue entender onde está e o que está acontecendo Embora fraco, consegue caminhar e sentir o alívio de estar fora da prisão e longe da violência. Chegou a uma lancheria, onde, ao compreender que o grande movimento naquele estabelecimento era devido à partida entre Brasil e Itália, final da Copa do Mundo, resolveu finalmente comer, visto que há dias não estava sendo bem alimentado. Sairia dali após o jogo, depois de comer e beber uma cerveja, "[...] mais preocupado em passar o tempo do que com a decisão de qualquer campeonato." (SCHNEIDER, 2019, p. 85). Porém, tal momento de alívio e tranquilidade individual seria interrompido:

Raul instalou-se na mesinha, fechou os olhos por um instante e suspirou, a gozar aquele momento. Depois, deu-se conta de que aqueles gestos, por algum motivo ainda desconhecido ou mesmo sem qualquer motivo, poderiam chamar a atenção, e então se entristeceu: seria assim para sempre de agora em diante, censurando a si mesmo [...]. Quem ali saberia da ditadura e lutaria contra ela, quem era admirador dos milicos e do general Médici? Quem seria policial? E havia entre esses homens algum infiltrado, olhando o jogo e espiando os demais? Examinou disfarçada mente os gestos e as maneiras dos mais próximos e desistiu: todos poderiam ser tudo. [...] $\mathrm{Na}$ porta de entrada da lanchonete, dirigindo a Raul um sorriso cujo significado não se podia adivinhar, estava o carcereiro. (SCHNEIDER, 2019, p. 85 - 87) 
O carcereiro, já conhecido do dono da la ncheria, e tendo o privilégio de sempre ser atendido preferencialmente e nunca ser cobrado, permaneceu junto a Raul durante toda a partida, manifestando um comportamento de poder sobre o prisioneiro recém-solto e apavorado com sua presença. Cada lance do jogo, fossem gols ou lances de perigo de a mbos os times, era motivo de euforia para os demais clientes reunidos na lancheria, mas, para Raul, não passava de um momento que ele não via a hora de terminar, dadas as provocações do carcereiro, que havia deixado cla ro o fato de saber tudo sobre Raul e o a meaçado. Raul, mesmo com o corpo dolorido, sem forças para andar e emocionalmente abalado, teve que fingir estar bem e simular atitudes de empolgação com a inevitável vitória da seleção brasileira. Os gols do Brasil eram interrupções nas intimidações do carcereiro a Raul.

Uivou um grito de "gol" que mais parecia um choro [...], e de repente começou realmente a chorar.

- Que é isso, rapaz? Não vai me dizer que é fresco? - Gozou o carcereiro frente às lágrimas súbitas do outro [...]

- Não, me desculpa... - gaguejou Raul. - Não sou fresco não, é que... muita coisa acontecendo ao mesmo tempo... [...]
- Que muita coisa o quê, rapaz! Hoje só tem uma coisa: Brasil tricampeão! O resto não existe, entendeu? Não existe! - E separou bem as sílabas da última frase [...] (SCHNEIDER, 2019, p. 136)

A alegria pela vitória da seleção brasileira foi grande, e o público começou a cantar os versos ufa nistas da canção Eu te amo meu Brasil, de Dom e Ravel. O carcereiro ordenou que Raul fosse embora, que cuidasse muito por onde andasse, e que não deveria cantar, pois não sentia a música no coração e o lugar dele não era junto de quem torceu pelo Brasil. A prisão equivocada de Raul foi resultado das ações arbitrárias da polícia, sob a permissividade do AI-5. Descoberto o equívoco, após toda a violência sofrida, o prisioneiro foi solto, mas sem qualquer atitude de reparação ao erro por parte da polícia, pelo contrário, permaneceu a desconfiança qua nto a ele ser comunista, devendo, pois, ser sempre vigiado. Logo, o protagonista, tal qual o próprio país, teria dificuldades para estar livre de seu recente passado traumático, pois ele sempre estaria presente.

\section{PASSADO SEMPRE PRESENTE E SUA BUSCA \\ POR RESSIGNIFICAÇÃO}

Momentos e eventos violentos permanecem presentes na atualidade do país, tal como um ferimento não 
cicatrizado, o que remete às definições psicanalíticas de Jean Laplance para trauma, no Vocabulário de psicanálise:

Acontecimento da vida do sujeito que se define pela sua intensidade, pela incapacidade em que se encontra o sujeito de reagir a ele de forma adequada, pelo transtorno e pelos efeitos patogênicos duradouros que provoca na organização psíquica.

Em termos econômicos, o traumatismo ca racteriza-se por um afluxo de excitações que é excessivo em relação à tolerância do sujeito e à sua capacidade de dominar e de elaborar psiquicamente estas excitações. (LAPLANCHE, 2001, p. 522)

Mesmo que tal postulado diga respeito a um indivíduo, alguém que é ferido, é possível pensá-lo em sentido mais a mplo, uma coletividade. Pensar o conceito do micro para o macro: exatos 35 anos separam o país do final de sua ditadura militar, porém, não há como negar suas consequências, tanto de modo particular em pessoas e seus parentes e a migos, qua nto no sentido coletivo. Tal período violento excessivo em relação ao que pode ser suportado e elaborado, permanece doloroso e rememorado, em diferentes formas. Aleida Assmann (2011) diferencia duas formas possíveis de memória: ARS e VIS. A primeira, ARS, “arte”, no sentido de técnica, diz respeito a armazenamento por meios materiais, passível de ser reproduzido, de modo que o destina tá rio receba o conteúdo na íntegra, e, quando é feito pela memória humana, chama-se mnemotécnica.

É problemático dizer que a ditadura já está distante o suficiente no tempo para a considerarmos apenas como algo registrado na primeira modalidade, ARS, na qual os acontecimentos ditos principais esteja $\mathrm{m}$ registrados nos livros e neles estudados, e cuja vida permanece apenas pela pesquisa histórica e científica. Afinal, ainda há uma memória latente, viva na forma de trauma em vários sobreviventes: a segunda, VIS, "potência”, que tra ta de recordar em detrimento de simplesmente guardar a informação. Enquanto ARS está mais relacionada a memórias guardadas e registradas propositalmente e de modo consciente, VIS significa recordar experiências pessoais vividas, de modo a reconstituir o que foi vivido, o que está sujeito a alterações e distorções, dada a característica subjetiva da memória humana. E é justamente neste sentido que diversos ocorridos no período militar ainda se fazem presentes na forma de comportamentos socia is internalizados e repetidos.

Sigmund Freud (1996), em um trabalho intitulado Recordar, repetir e elaborar, originalmente publicado em 1914, começa a desenvolver a ideia de repetição. À época, seus pacientes, por meio de hipnose, eram motivados a 
recordar eventos traumáticos, de modo a revivê-los no momento da consulta. Tal técnica, com o tempo, Freud iria repensar, e, em sua revisão, abandonaria a hipnose e passaria a usar a associação livre, na qual o paciente falaria livremente e, por meio da superfície de sua fala, Freud iria identificar bloqueios e resistências que protegem o paciente do sofrimento de lembrar e rememorar os tra umas sofridos. Ou seja: em vez de lembrar o trauma recalcado, ele a tua. Inconscientemente, o paciente repete, com o terapeuta, o comportamento que tivera quando sofreu os traumas. Seis a nos depois, em um trabalho intitulado Além do princípio de prazer, o autor se aprofundaria ainda mais em suas descobertas, apontando que determinados eventos vivenciados eram tão pesados que suas memórias permaneciam recalcadas no inconsciente, sem ja mais serem escritos, representados ou simbolizados, como que uma energia presa que se transformaria em sintoma. Assim, o paciente, de modo inconsciente, seguiria se submetendo, de modo inconsciente, em vivências tra umáticas, como um ciclo compulsivo de repetição, um padrão, tal como aponta Ginzburg em relação ao pós-trauma dos regimes violentos no país:

Embora tenhamos formalmente deixado os regimes ditatoriais, uma série de condutas, correntes ideológicas, padrões comportamentais e valores morais consolidados dentro desses regimes se desdobraram e difundiram, atingindo a sociedade brasileira até o momento presente. Ocorreram mudanças, mas estas não são suficientes para eliminar as fantasmagorias e seus resíduos, que constantemente reaparecem. (GINZBURG, 2010, p. 126)

O autor localiza a origem deste padrão de comportamento repetitivo no nosso passado colonial, escravista, patriarcal, funda mentado em ações de repressão e violência. Essa violência é, então, algo constitutivo nas nossas relações sociais. A esta compulsão à repetição ao nível macro a psicanalista Maria Rita Kehl define como traumas vivenciados coletiva mente, e que, tal como o paciente com energia do trauma precisando de representação, o país precisa de uma elaboração para seu passado traumático, mesmo que negacionistas tentem levar esta memória coletiva para um esquecimento, que possui sintomas:

Somos então obrigados a nos indagar se é possível se falar em um inconsciente social cujas representações recalcadas produzem manifestações sintomáticas. [...] O sintoma social se manifesta por meio de práticas e discursos que se automatizam, independentes das estruturas psíquicas singulares de cada um de seus agentes. [...] Se o trauma, por sua própria definição de real não simbolizado, produz efeitos sintomáticos de repetição, as tentativas de esquecer os eventos traumáticos coletivos resultam em sintoma social. Quando uma sociedade não consegue 
elaborar os efeitos de um trauma e opta por tentar apagar a memória do evento traumático, esse simulacro de recalque coletivo tende a produzir repetições sinistras. (KEHL, 2010, p. 124 - 126)

Assim, a história política do país encontra-se em um longo ciclo vicioso de repetição. Mesmo que estejam encerrados os momentos mais violentos e autoritários, o ato de calar e eliminar opositores sempre fez parte da nossa história, e serve ainda como uma referência principal de conduta, não só governa mental, mas em relações pessoais e profissionais comuns, até mesmo na forma de pequenas violências discursivas do cotidiano, que, de tão naturalizadas, podem não ser percebidas. No sentido governamental, isso explica a insistência de determinados líderes políticos ainda referenciarem a ditadura em suas falas e reproduzirem ainda comportamentos de truculência, principalmente contra ma nifestantes, artistas e a imprensa. A violência, oriunda do a utorita rismo, produziu tra umas que, como tais, necessitam de uma elaboração. Porém, ao serem submetidos a um esquecimento forçado, seguem buscando uma ressignificação por meio desta repetição viciosa da violência no decorrer das décadas.

Para Assmann (2011), um trauma seria uma

Experiência cujo excedente ultrapassa a capacidade psicofísica", que "trata de destruir a possibilidade de uma autoconstituição integral. [...] Estabiliza uma experiência que não está acessível à consciência e se firma nas sombras dessa consciência como presença latente. (2011, p. 277).

Então, há de se indagar: de que modo superar este trauma coletivo e romper com este padrão? A resposta se dá pela elaboração também coletiva e pública destes traumas: na forma de estudos e reflexões tanto em âmbito acadêmico como informal, em atitudes reparadoras por parte do estado a todas as vítimas e seus familiares e amigos, e, principalmente, que essas pessoas traumatizadas seja m ouvidas e lidas. Para a autora, o próprio léxico é um fator cooperativo na elaboração do trauma:

A língua é o estabilizador mais poderoso das recordações. E muito mais fácil lembrar-se de algo que tenha sido verbalizado do que de algo que nunca tenha sido formulado na linguagem natural. Quando ocorre a verbalização, não nos lembramos mais dos acontecimentos em si, mas da nossa verbalização deles. Os signos linguísticos funcionam como nomes, com os quais objetos e situações podem ser evocados nova mente. Pela língua, recordações individuais são estabelecidas e socializadas. (ASSMANN, 2011, p. 267 - 268)

A fala tornaria a experiência partilhada e, portanto, com maior poder de elaboração. Kehl (2010) afirma que 
5. Disponível em < http://www. planalto.gov.br/ccivil_o3/leis/L6683.
$\mathrm{htm}>$, acessado em 29 out. 2019. estes sobreviventes, em virtude de seu trauma, vivem em um universo à parte, pelas inúmeras dores e perdas que carrega m e pelos registros de sofrimento em seus corpos, mas ta mbém porque tais práticas dos torturadores ja mais fora $m$ reconhecidas e reparadas publica mente, pelo contrá rio: a Lei da Anistia, de 28 de agosto de 1979, embora tenha possibilitado o retorno de presos políticos exilados, isentou os militares de assumirem seus crimes e passarem por suas respectivas condenações ${ }^{5}$. Ainda segundo Kehl (2010), tais remanescentes nunca se recusaram a elaborar publicamente seu trauma, e, nas últimas duas décadas, muitos estudos em â mbito acadêmico fora m realizados, muitos textos de reflexão e denúncia, tanto de autoria das próprias vítimas como de seus parentes, foram publicados.

Esse ca minho para a elaboração do trauma, por meio da socialização, da simbolização, do registro e da representação, tem sido realizado. $E$ as forças que insistem no apagamento e no esquecimento estão junto aos remanescentes do próprio regime militar, muitos ainda em atividade na política.

São estes os que se recusam a enfrentar o debate público com a espantosa conivência da maioria silenciosa, a mesma que escolheu permanecer alheia aos abusos cometidos no país, sobretudo no período pós-AI-5. Muita gente ainda insiste em pensar que a prática da tortura teria sido (ou ainda é) uma espécie de mal necessário imposto pelas condições excepciona is de regimes autocráticos, e que sob um regime democrático não precisa mos mais nos ocupar daqueles deslizes do passado (KEHL, 2010, p. 126 - 127)

Assim, para uma superação dos traumas, sociedade e estado precisam ter ações efetivas. À sociedade, cabe estudar de modo abrangente o assunto e falar a respeito dele de modo lúcido; e, ao estado, cabe reconhecer publicamente seus excessos, reparar suas consequências e reprimir qualquer tentativa de minimizá-las. Esta seria uma forma possível de elaboração do trauma coletivo, que, bem conduzida, e sintomatizando na forma de produções artísticas que contribuam para o debate, ajudará o país a romper com este passado autoritário de modo conciliador, não na forma de esquecimento forçado, que só produzirá repetições.

\section{O TEXTO LITERÁRIO AFETADO PELO TRAUMA QUE REPRESENTA}

Como modo de elaboração do trauma coletivo, em vez de optar pelo esquecimento como uma tentativa de reprimir e negar os fatos, é preciso lembrar cada vez mais, representar, simbolizar, refletir, para que o esquecimento venha em forma de superação e rompimento com o 
trauma, e não como uma negação deste. A leitura de textos literá rios, conforme Ginzburg (2010), contribui para evitar a banalização e naturalização da violência, e o ato de ignorar sua intensidade e seu impacto levaria a população ao esquecimento, que seria uma catástrofe coletiva pois haveria a possibilidade de algo semelhante voltar a acontecer no país. A literatura, o cinema, o teatro e as histórias em quadrinhos, bem como outras modalidades artísticas, seguem trabalhando com o assunto, e há diversos exemplos de produções que tiveram grande alcance de público, gerando importantes reflexões.

Contudo, o modo de gerir a política no período militar não afetou apenas a polícia, a economia, a educação e as relações, mas ta mbém a linguagem literária, bem como as condições de sua produção. $\mathrm{O}$ tema tortura, associado à ditadura, dada sua veracidade factual e suas consequências ainda visíveis, é de natureza diferente de qualquer outro tema que um autor venha a representar em seu texto ficcional. Ginzburg (2001) aponta que as mudanças na concepção dos textos literários são inevitáveis, pois a perplexidade dos acontecimentos representados não pode ser assimilada sem que se sinta ou sofra seu impacto, e isso abala as bases do pensamento, que costuma acomodar as informações em lógicas lineares. Se a forma comum e linear de processamento e organização de pensamento fosse aplicada no ato de organizar um texto ficcional que visa a representar acontecimentos traumáticos, ela poderia banalizá-los, o que tiraria sua perplexidade, que é justa mente o que os impede de serem naturalizados como coisas do cotidiano. Em Setenta, é possível enumerar pelo menos duas características oriundas da própria natureza dos eventos traumáticos representados: o descentramento do foco narrativo e a fragmentação.

\subsection{FRAGMENTAÇÃO: DO SUJEITO AO TEXTO}

A experiência vivenciada pelo personagem Raul, do romance Setenta, pode ser vista como uma experiência real no sentido de que torturas realmente aconteceram secreta mente em 1970, enqua nto exteriormente divulgava-se a imagem de um país em grande desenvolvimento, mirando em um futuro promissor. A vitoriosa campanha da seleção brasileira, na Copa de 1970, foi uma grande ferramenta para a manutenção desse discurso. Mas, como ficcionalizar algo sem que este algo afete o próprio texto que o representa? Dado que o tema principal de Setenta seja a tortura, há uma determinada característica deste ato na vítima: a dissociação entre o corpo e o sujeito dono deste corpo, e isso se fará presente ta mbém ao nível textual. Maria Rita Kehl (2010) aponta que a tortura refaz o que se entende por dualismo entre o corpo e a mente, ou o corpo e o espírito. $\mathrm{O}$ corpo é assujeitado à diversão do 
torturador, de modo que aquilo que fala, pensa e simboliza vai além dos imites da carne, fica à deriva. Em outras palavras: o sujeito, dissociado de seu corpo, deixa de controlá-lo, sua própria fala já não mais lhe pertence, afinal, o torturador tira de sua vítima o que ele quer ouvir, e não o que ela teria a dizer. Desse modo, ao torturado, resta apenas o silêncio e a sensação de não conseguir mexer seus braços e pernas, como se seu corpo estivesse fragmentado, cada parte separada e fora de controle.

O corpo permaneceu inânime ainda por alguns minutos; depois, muito aos poucos, começou francamente a voltar a si. [...] Ficou assim, quase sem se mexer, os olhos fechados, apenas sentindo-se respirar e certificando-se de que todas as partes do seu corpo ainda existiam. (SCHNEIDER, 2019, p. 146)

A fragmentação ta mbém diz respeito ao tempo, visto que a vítima perde a noção de quantos dias se passaram e da cronologia do que lhe aconteceu, sua capacidade de pensar não lhe permitirá rememorar e organizar os acontecimentos. Tal característica da tortura ao torturado afeta a construção do texto: cada capítulo do livro possui uma data, e elas não estão em ordem. Os fatos não são apresentados em ordem cronológica ao leitor. Tudo acontece em um intervalo de tempo de dez dias, entre o dia 12 e o dia 21 de junho de 1970, domingo, dia da final da Copa do Mundo e da soltura de Raul.

A fragmentação do texto é dada ao leitor, que, sob efeito do horror das descrições de violência, precisa rememorar o que leu, organizar os fragmentos cronologicamente e compreendê-los na sua totalidade, não em fragmentos. Assim como o torturado, que precisará se situar novamente em relação aos acontecimentos que vivenciara e readquirir a totalidade de seu fragmentado corpo. Isso pode causar, no leitor, a impressão de que todo o sofrimento de Raul durou muito mais do que dez dias, tal como pode parecer, ta mbém, ao próprio personagem em relação à violência que acabara de sofrer. A fragmentação do texto lhe deu um formato cíclico, pois ele termina exatamente onde começou: o momento em que Raul pela primeira vez abriu os olhos e viu o sol depois de tantos dias preso, e foi ofuscado pela claridade. Ginzburg (2001), em relação à fragmentação de textos ficcionais que representam autoritarismo e violência, pontua que ela é importante no sentido de "desfazer qualquer impressão de normalidade" (2001, p. 141), pois a ausência da perplexidade levaria à naturalização da barbárie em detrimento da reflexão sobre suas causas e possíveis modos de evitar que se repita. 


\subsection{DIFERENTES VOZES: DESCENTRAMENTO}

\section{DO FOCO NARRATIVO}

Ginzburg (2010) fala sobre as mudanças nas condições de produção literária, principalmente no que diz respeito a "[...] renovações de linguagem e rupturas com valores tradicionais [...]", e uma destas características seria o descentramento do foco narrativo, e ele seria uma forma de "[...] aproximação de conflitos da realidade histórica, abrindo mão do realismo tradicional em sentido estrito, em que o narrador é onisciente e o tempo é ordenado [...]" (2010, p. 139). Assim, tal marca acrescentaria mais profundidade a determinados personagens fora do núcleo principal de ação que, em Setenta, é o de Raul enquanto preso. O livro, em pelo menos quatro capítulos, muda o foco da narração para o ponto de vista da mãe de Raul, na forma de um monólogo, em que ela aparece falando com alguém, ora um padre ora um policial:

Bom dia, seu policial, bom dia. O senhor me desculpe eu ir entrando assim, não sei se precisa pegar ficha e aguardar a cha mada, mas é que não consegui esperar. É a primeira vez que entro numa delegacia e já esperei todo o fim de semana. Desde sexta-feira, imagine. E, além disso, estou desesperada. Desculpe eu chorar enquanto falo. O senhor me escute, por favor. Meu nome é Irene e quero registrar um desapa recimento.

O desaparecimento do meu filho. O nome dele é Raul. Rau dos Santos Figueira. O meu filho. [...] O Raul não passa uma noite fora de casa. Se isso aconteceu, foi uma ou duas vezes na vida, e ele sempre deu um jeito de avisar. (SCHNEIDER, 2019 , p. $33-34)$

O capítulo 10, narrado ainda em terceira pessoa, muda o foco da ação, introduz o carcereiro, que, apresentado no capítulo anterior, parece ter um comportamento mais moderado no trato com os presos. Ele conversa mais com Raul, e a té descobre algo em comum com ele: a devoção por Nossa Senhora Aparecida. No sentido de explorar mais o personagem, o capítulo apresenta um pouco de sua vida particular na forma de um momento com a família e algumas descrições de seus pensamentos, como vê a vida e o que pensa sobre os opositores:

Era uma festinha pequena, apenas os primos e dois ou três a miguinhos brincando na garagem improvisada. Nem mesmo havia convidado seu chefe, embora soubesse que, bem aproveitada a visita, esta talvez até lhe pudesse render alguns pontos positivos. Isto era o mais importante, pensou o carcereiro: a fa mília. Por isso não conseguia compreender como havia gente - aqueles comunistas, subversivos, os socialistas (era assim mesmo a palavra?) - que podia ser contra esses valores que só fazia m bem. Por que alguém poderia ser tão contra a família a ponto de comer criancinhas, como o chefe havia lhe dito que 
faziam na Rússia? [...] Matar, matar - porque esse tipo de gente não merecia viver. (SCHNEIDER, 2019, p. 76 - 78)

Todo o romance é escrito de modo predominantemente descritivo, apresentando os demais torturadores de modo unilateral, sendo que cada um representa, em maior ou menor grau, características de pessoas que servem ao a utoritarismo: a irresponsabilidade, o sadismo e a banalização da violência. A irresponsabilidade é apresentada pela reação do delegado no momento em que foi informado de que prendera a pessoa errada. Este estava mais preocupado com o que poderia lhe acontecer do que com o da no causado ao inocente preso e torturado. O sadismo apa rece em Raposo, que demonstra notável diversão com o sofrimento de Raul, sendo capaz de sentir algo lúdico na tortura. A banalização da violência é visível nos qua tro oficiais de plantão, responsáveis pela arbitrária e truculenta prisão de Raul. Eles levam uma vida comum de ida e volta do trabalho, e conversam normalmente nos plantões, uma normalidade dissociada da natureza violenta de seus trabalhos diários. Tais características não são desenvolvidas na forma de pequenos arcos para cada personagem, apenas são visíveis nas descrições do tempo de prisão de Raul. Não há outros capítulos dedicados a apresentar outros personagens além da mãe de Raul e do carcereiro.

\section{CONSIDERAÇÕES FINAIS}

Os dois descentramentos de foco narrativo, mãe e carcereiro, colocados dentro de uma narrativa completamente fragmentada, acrescenta ao romance o que Ginzburg (2001) chama de "[...] renúncia aos modos convencionais de representação, pois estes seriam incapazes de preservar a singularidade da experiência e a perplexidade [...]" (p. 132 - 133), sem as quais o sofrimento de Raul, embora fictício, mas inspirado pelos relatos de remanescentes da ditadura, fica ria banalizado. A essas desorganizações formais, Assma nn chama de contra modelo da narrativa básica, chamado de colagem. Esse recurso "[...] 'quebra' a espinha dorsal da narrativa, a sequência temporal-cronológica”, e [...] 'rompe' nexos entre acontecimentos e distribui fragmentos de arra njos livres [...]". A colagem, portanto, não é "[...] apenas uma forma de perda da ordenação, mas também uma forma de abalo da ordem [...]" (2011, p. 306). De acordo com a autora, a escrita, no sentido de registro e reconstituição de traumas, ta mbém serve como um estabilizador material para memórias traumáticas, tanto individuais como coletivas. A própria capa de capa de Setenta possui um significativo elemento de simbolização: a bandeira do Brasil, como que pintada em uma parede, com seu círculo azul no formato de uma pessoa em posição fetal, de modo a fazer referência direta ao primeiro monumento construído 
6. Disponível em: https://visit.recife. br/o-que-fazer/atracoes/monumentotortura-nunca-mais. Acessado em 22 out. 2019. em memória aos mortos e desaparecidos por motivações políticas no país durante o período militar. Ele se chama Monumento Tortura Nunca Mais, de autoria do arquiteto piauiense Demétrio Albuquerque, e está situada em Recife $^{6}$. O que a ilustração comunica, ao leitor, fica claro ao final da leitura do livro: a bandeira do Brasil, durante a Copa do Mundo do México de 1970, era usada para propagar uma imagem positiva do país, porém, há uma antítese a essa euforia, que é o que ocorria secreta mente nos porões, onde opositores ao governo - ou meros suspeitos, no caso de Raul - eram interrogados e cruelmente torturados. De modo irônico, a epígrafe do livro é a fala de Alfredo Buzaid, ministro da justiça entre os anos de 1969 e 1974: "não há tortura no Brasil” (SCHNEIDER, 2019 , p. 5), justamente no período em que fora m intensificadas as perseguições e prisões de opositores. A escrita do romance parece ter sido feita como uma resposta à epígrafe, uma negação dela, e é possível inferir que foi sintomática de uma disputa de narrativa extratextual. Uma luta entre defensores da elaboração e reparação do trauma contra os que não percebem se cumprir, no país, o referido conceito de compulsão à repetição de Freud nosso trauma coletivo possui uma energia latente, contida, que, caso não seja discutida, simbolizada e reparada continuará a produzir repetições.
Henrique Schneider, por meio de uma equilibrada ruptura com o tradicional, também apontada por Ginzburg (2001), apresenta um nível de descrição necessário para preservar a perplexidade dos acontecimentos narrados, o que, caso não feito, contribuiria para sua banalização, que é justa mente contra o que combatem os sobreviventes dos porões da ditadura, bem como os estudiosos das ciências humanas e muitos artistas por meio de suas obras.

\section{REFERÊNCIAS}

ASSMANN, Aleida. Espaços da recordação: formas e transformações da memória cultural. Tradução: Paulo Soethe. Campinas: Unicamp, 2011.

FREUD Sigmund. Além do princípio de prazer. In: Edição Standard Brasileira das Obras Psicológicas Completas de Sigmund Freud, vol. XVIII. Rio de Janeiro: Imago, 1996.

FREUD, Sigmund. Recordar, repetir e elaborar: novas recomendações sobre a técnica da psicanálise II.

In: Edição Standard Brasileira das Obras Psicológicas Completas de Sigmund Freud, vol. XII. Rio de Janeiro Imago 1996 
GINZBURG, Jaime. A violência constitutiva: notas sobre autoritarismo e literatura no Brasil. In: Letras - Revista do Programa de Mestrado em Letras da UFSM, v. 18/19 Edição Especial - Quinto Centenário. Publicado em 2001.

Disponível em: < https://periodicos.ufsm.br/letras/article/ view/12080/7484 > , acessado em 19 out. 2019. p. $121-144$.

GINZBURG, Jaime. Escritas da tortura. In: O que resta da ditadura: a exceção brasileira / Edson Teles e Vladimir Safatle (Orgs). São Paulo: Boitempo, 2010.

GINZBURG, Jaime. Literatura brasileira após Auschwitz. In Alea: Estudos Neolatinos (Impresso), Rio de Janeiro, v. 3,

n.2, p. 117-126, 2001.

KEHL, Maria Rita. Tortura e sintoma social. In: O que resta da ditadura: a exceção brasileira / Edson Teles e Vladimir Safatle (Orgs). São Paulo: Boitempo, 2010.

LAPLANCHE, Jean. Vocabulário de psicanálise / Laplanche e Pontalis; sob a direção de Daniel Lagache. Tradução de Pedro Tamen. 4a ed. São Paulo: Martins Fontes, 2001.

SHNEIDER, Henrique. Setenta. Porto alegre: Não Editora, 2019

Recebido em: 14/01/2020

Aceito em: 13/10/2020

EM TESE

BELO HORIZONTE

v. 26

N. 2

MAIO-AGO. 2020

JACQUES. Setenta, de Henrique Schneider: tortura, trauma [...] 